\title{
FORMATION OF THE COLLECTION OF THE FOREIGN ARTISTS DURING THE ESTABLISHMENT OF ISTANBUL PAINTING AND SCULPTURE COLLECTION*
}

\author{
Şeyda ÜSTÜNIPEK \\ İstanbul Arel University, Turkey \\ seydaustunipek@arel.edu.tr
}

\begin{abstract}
Following the establishment of the Istanbul Painting and Sculpture Museum in 1937, a group of important figures of the Paris School were taken to the museum collection. Selahattin Refik Sirmali Bey, who is the owner of the leading decoration store of the period, took an active role in the formation of a foreign collection in the museum. It is also known that Léopold-Lévy, who served as the head of painting department at the Istanbul State Academy of Fine Arts, was a contact for the introduction of these paintings brought from Paris by Selahattin Refik. This initiative of Lévy, who was assigned to the organization of the museum after his arrival in Istanbul, made a significant contribution to the formation of foreign collections, and there is no indication that these works were purchased from Selahattin Refik Sirmalı Bey in the museum records. The collection involves the leading names of modern painting like Pierre Bonnard, Maurice Utrillo, Pablo Picasso, Henri Matisse, Raoul Dufy, Andre Derain, as well as Charles Despiau (sculptor), Eduard Kayser, A.Dunayer de Segonzac with their prints. Foreign artists in the collection are the representatives of modern painting of early $20^{\text {th }}$ century. Their works in the collection were in the agendum of Turkish press of that period and during the Second World War they provided a link to follow modernism in art for Turkish painters who were not able to visit western art centres.
\end{abstract}

Keywords: Istanbul Painting and Sculpture Museum, Collection, Foreign artists, Modernism, Selahattin Refik Sirmall, Léopold-Lévy.

\section{İSTANBUL RESIM HEYKEL MÜZESININ KURULUŞ SÜRECINDE YABANCI SANATÇILAR KOLEKSIYYONU}

\section{$\ddot{\mathbf{O Z Z}}$}

1937 yılında İstanbul Resim Heykel Müzesi'nin kuruluşunun ardından, müze koleksiyonuna çoğunluğu Paris ekolünün önemli isimlerinden oluşan bir grup resim alınmıştır. Müzede yabanc1 koleksiyonun oluşmasında dönemin önde gelen dekorasyon mağazasının sahibi olan Selahattin Refik Sırmalı Bey aktif rol almıştır. Selahattin Refik' in Paris’ten getirdiği öne sürülen bu resimlerin müzeye kazandırılmasında İstanbul Devlet Güzel Sanatlar Akademisi'nde resim bölüm başkanı olarak görev yapan Léopold-Lévy'nin köprü olduğu da bilinmektedir. İstanbul'a geldikten kısa bir süre sonra müzenin düzenlenmesi ile de görevlendirilen Lévy'nin bu girişimi yabancı koleksiyon oluşumuna önemli bir katkı sağlarken müze kayıtlarında bu eserlerin Selahattin Refik Sirmalı Bey'den satın alındığına dair bir not yoktur. Pierre Bonnard, Maurice Utrillo, Pablo Picasso, Henri Matisse, Raoul Dufy, Andre Derain gibi modern resmin öncü isimlerinin yer aldığ koleksiyon, yine Charles Despiau

\footnotetext{
This paper was presented at the 15th International Congress of Turkish Art, in Naples (Università di Napoli "L'Orientale", at 16th-18th September 2015
} 
(heykeltraş), Eduard Kayser, A.Dunayer de Segonzac'ın baskı resimlerini içermektedir. Koleksiyona katılan yabancı sanatçılar aynı zamanda yirminci yüzyıl başında modern resmin temsilcileridir. Bu eserler İkinci Dünya Savaşı sırasında yurtdışına gidemeyen Türk ressamların modernizmi izlemelerine yardımcı olmakla birlikte, dönemin basınının da uzun süre gündeminde yer almışlardır.

Anahtar Kelimeler: İstanbul Resim Heykel Müzesi, Koleksiyon, Yabancı ressamlar, Modernizm, Selahattin Refik Strmalı, Léopold-Lévy.

\section{INTRODUCTION}

Formation of a collection in Ottoman court has begun in the second half of the 19th century with acquisitions of some local and foreign painters. When Osman Hamdi Bey was the director of Müze- i Hümayun (Royal Museum) he has also made efforts on establishing a museum of arts. His brother Halil Ethem has carried on these efforts after his death and in the early years of 20th century collection has been enriched by ordering copies of some western masterpieces along with Turkish, non- Muslim Ottoman and foreign artists. While the initiative of Halil Ethem has been the first official attempt, the establishment of Istanbul Painting and Sculpture Museum has been realized during the Turkish Republic period.

While the Istanbul Painting and Sculpture Museum was being organized, a group of foreign paintings were added to the collection. It is the primary purpose of this study to convey the inclusion of these paintings, which are the works of the pioneer names of the Paris School and modern painting, into the collection. This work is limited to this group picture, which is specified in the table with the text. In this context, a literature study including the data in the Prime Ministry State Archive, the Archives of the Istanbul Museum of Painting and Sculpture and the writings in the press were made.

\section{Establishment of Istanbul Painting and Sculpture Museum}

According to State Archives, date of the decision for establishing a museum was in 24 July 1937. "Veliaht Dairesi" of Dolmabahçe Palace has been assigned as a museum building in 18 August 1937. From the document dated to 24 July of 1937 it is understood that a selection has been made from the works which had been previously bought by State and were in the collections of public offices and banks in Ankara. The first director of the museum Halil Dikmen has been in the capital city for to make a selection among them. Afterwards selected works have been evaluated by a jury in Istanbul for the final decision of collection pieces. (Archivea,1937)

Cemal Tollu who had worked during the establishment of the museum has cited that a comission has been formed at the Academy for the final selection and Léopold-Lévy who had been appointed as the head of Painting Department in early 1937 has also attended that busy process. Finally the collection has been organized at the halls according to their periods and styles. (Tolllu, 1967:38)

French painter Léopold-Lévy has been invited to Istanbul as the head of Painting Department at he Fine Arts Academy while Burhan Toprak was the director (10 April 1936- 19 July 1948). As a result of reorganizing the Academy by appointing qualified artists of related fields Lévy has arrived to Istanbul with his family in December 1936. He has been the head of Painting Department and Litography atelier. He has also worked for the establihment of Istanbul Painting and Sculpture Museum. (Üstünipek, Ş., 2009: 71) 


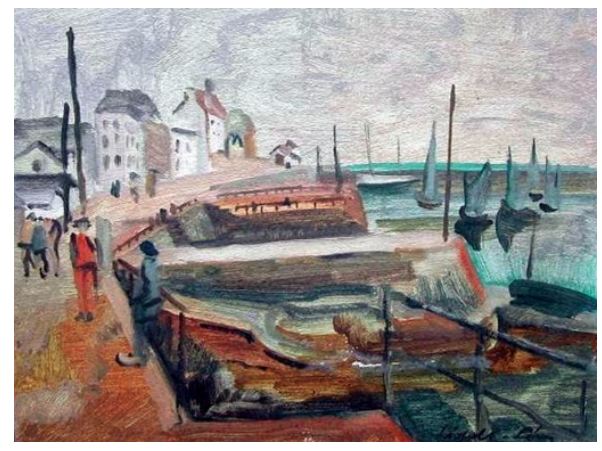

Picture 1. Léopold-Lévy; Wharf, oil on board, 27x35cm, Istanbul Painting and Sculpture Museum Collection (Ref. Katipoğlu, H. (ed.) (1996). İstanbul Resim Heykel Müzesi Kataloğu, YKY, İstanbul, s.90)

According to Tollu, the exhibition of "Fifty Years of Turkish painting" which was organized by Burhan Toprak has been very important for the idea and intention of establishing a museum of arts. During the formation of museum collection Léopold-Lévy has also included the works of younger artists whose works had been shown in that exhibition. These young artists were mostly the members of Müstakil Ressamlar ve Heykeltraşlar Birliği (Association of Independent Painters and Sculptors) and $d$ Grubu (Group d). As a result of Lévy's attitude towards younger artists they have also been represented in the museum collection. Thus the museum has consisted of selected works showing the relatively brief past and present of Turkish painting and sculpture. The museum has been opened with the presence of Atatürk in 20th of September 1937.

\section{The collection of foreign artists in the Istanbul Painting and Sculpture Museum and Selahattin Refik Sirmalı cooperation}

The collection of foreign artists in the museum dated to 20th of July 1939. Remarkable statements about this group of paintings have been claimed in Burhan Toprak's speech during the opening of Léopold-Lévy exhibition at he Academy in 16 April 1938.

"A first attempt was realized by Selahattin Refik Sirmalı cooperation. While we were trying to shape an art market in Turkey he bought the paintings and gravures of most important artists in Paris and brought them to Turkey. We are going to show these works at the Academy after Léopold-Lévy's exhibition." (Anonymusa, 1938: 9)

The cooperation of Selahattin Refik Sirmalı which has been mentioned in the speech of Burhan Toprak was belonging to Selahattin Refik Sirmalı. Sirmalı was the most important decorator of the early Republic period who had opened decoration stores in Çemberlitaş Vezir Han in 1914, in Galata in 1915 and in Ankara after the declaration of Republic. He has decorated some important state buildings: Ziraat Bank and İş Bank in Ankara, chamber of Atatürk in Çankaya Kiosk and Pembe Kiosk were his major comissions. (Tosun; Özsu, 2014: 219,220) In the early 1930's he has removed to Istanbul and opened a store called "Dekorasyon" in Nur-u Ziya street. (Üstünipek,Ş.2009: 422) Known with his art deco designs, in that store of Sirmalı some works for the international UNESCO exhibition have been shown. (Üstünipek, M.2013: 820 )

His collaboration with Ernst Egli, the head of Architecture Department of the Academy in the jury of Yıldız Sarayı Teftiş Projesi (Supervision Project of Yıldız Palace) contest proves his contact with Fine Arts Academy. (Tosun; Özsu, 2014: 219,220) 
We have the information about the formation of museums's foreign artists collection from the news in Cumhuriyet Newspaper in 16 July 1939 announcing the museums reopening. (Anonymusf, 1939; 2) It has been written that the museum collection was enriched with Turkish and foreign artists, a hall was organized for the works of foreign artists which was consisted of 26 pieces and they were bought by the Fine Arts Academy for the cost of 3000 liras. In that hall there have been exhibited 19 gravures of Picasso, Segonzac, Matisse, Despiau, Dufy, Laboureur, Léopold-Lévy, Kayser, Verge Sarrat eight oils of Bonnard, Derain, Marquet, Utrillo, Kayser and Léopold-Lévy.

\begin{tabular}{|c|c|c|c|c|c|c|}
\hline $\begin{array}{l}\text { Invent } \\
\text { ory } \\
\text { numbe } \\
\text { r }\end{array}$ & Artist & Title & $\begin{array}{l}\text { Date of } \\
\text { Entrance } \\
\text { to Museum }\end{array}$ & $\begin{array}{l}\text { Size and } \\
\text { technique }\end{array}$ & From & $\begin{array}{l}\text { Pri } \\
\text { ce }\end{array}$ \\
\hline 317 & $\begin{array}{l}\text { Piere Bonnard } \\
(1867-1947)\end{array}$ & $\begin{array}{l}\text { Landscape } \\
\text { Evening in the } \\
\text { Wernon }\end{array}$ & 20.07 .1939 & $\begin{array}{l}36 \times 34 \mathrm{~cm} \\
\text { Oil on canvas }\end{array}$ & $\begin{array}{l}\text { From } \\
\text { Fine } \\
\text { Arts } \\
\text { Academ } \\
\text { y }\end{array}$ & $\begin{array}{l}300 \\
\mathrm{~L}\end{array}$ \\
\hline 318 & $\begin{array}{l}\text { Andre Derain } \\
(1880-1954)\end{array}$ & $\begin{array}{l}\text { Road Lined with } \\
\text { Trees }\end{array}$ & 20.07. 1939 & $\begin{array}{l}46 \times 56 \mathrm{~cm} \text { Oil } \\
\text { on canvas }\end{array}$ & $\begin{array}{l}\text { From } \\
\text { Fine } \\
\text { Arts } \\
\text { Academ } \\
\text { y }\end{array}$ & $\begin{array}{l}500 \\
L\end{array}$ \\
\hline 319 & $\begin{array}{l}\text { Maurice Utrillo ( } \\
1883-1955)\end{array}$ & Church in Trees & 20.07 .1939 & $\begin{array}{l}38 \times 46 \mathrm{~cm} \\
\text { Oil on board }\end{array}$ & $\begin{array}{l}\text { From } \\
\text { Fine } \\
\text { Arts } \\
\text { Academ } \\
\text { y }\end{array}$ & $\begin{array}{l}200 \\
\mathrm{~L}\end{array}$ \\
\hline 320 & $\begin{array}{l}\text { Albert Marquet } \\
(1875-1942)\end{array}$ & $\begin{array}{l}\text { Impressions from } \\
\text { Napoli }\end{array}$ & 20.07 .1939 & $\begin{array}{l}21.5 \times 26.5 \mathrm{~cm} \\
\text { Oil on canvas }\end{array}$ & $\begin{array}{l}\text { From } \\
\text { Fine } \\
\text { Arts } \\
\text { Academ } \\
\text { y }\end{array}$ & $\begin{array}{l}200 \\
L\end{array}$ \\
\hline 321 & $\begin{array}{l}\text { Eduard Kayser } \\
(1882-1965)\end{array}$ & Tree and Road & 20.07 .1939 & $\begin{array}{l}38 \times 46 \mathrm{~cm} \\
\text { Oil on wood }\end{array}$ & $\begin{array}{l}\text { From } \\
\text { Fine } \\
\text { Arts } \\
\text { Academ } \\
\text { y }\end{array}$ & $\begin{array}{l}100 \\
L\end{array}$ \\
\hline 322 & $\begin{array}{l}\text { Leopold Levy } \\
(1882-1966)\end{array}$ & $\begin{array}{l}\text { Landscape } \\
\text { «Wharf» }\end{array}$ & 20.07 .1939 & $\begin{array}{l}27 \times 35 \mathrm{~cm} \\
\text { Oil on board }\end{array}$ & $\begin{array}{l}\text { From } \\
\text { Fine } \\
\text { Arts } \\
\text { Academ } \\
\text { y }\end{array}$ & $\begin{array}{l}150 \\
\mathrm{~L}\end{array}$ \\
\hline 323 & $\begin{array}{l}\text { Leopold Levy } \\
(1882-1966)\end{array}$ & $\begin{array}{l}\text { Landscape } \\
\text { «Wharf» }\end{array}$ & 20.07 .1939 & $\begin{array}{l}38 \times 55 \mathrm{~cm} \\
\text { Oil on board }\end{array}$ & $\begin{array}{l}\text { From } \\
\text { Fine } \\
\text { Arts } \\
\text { Academ } \\
\text { y }\end{array}$ & $\begin{array}{l}150 \\
\mathrm{~L}\end{array}$ \\
\hline 324 & $\begin{array}{l}\text { Laboureur (1877- } \\
1943 \text { ) }\end{array}$ & $\begin{array}{l}\text { Woman and Man } \\
\text { Walking in the } \\
\text { Rain }\end{array}$ & 20.07 .1939 & $\begin{array}{l}16 \times 13 \mathrm{~cm} \\
\text { Etching } \\
\text { (ofort) }\end{array}$ & $\begin{array}{l}\text { From } \\
\text { Fine } \\
\text { Arts } \\
\end{array}$ & $\begin{array}{l}73 \\
L\end{array}$ \\
\hline
\end{tabular}




\begin{tabular}{|c|c|c|c|c|c|c|}
\hline & & & & & $\begin{array}{l}\text { Academ } \\
\mathrm{y}\end{array}$ & \\
\hline 325 & $\begin{array}{l}\text { Laboureur (1877- } \\
1943)\end{array}$ & Woman Figure & 20.07 .1939 & $\begin{array}{l}23.5 \times 19 \mathrm{~cm} \\
\text { Etching } \\
\text { (ofort) }\end{array}$ & $\begin{array}{l}\text { From } \\
\text { Fine } \\
\text { Arts } \\
\text { Academ } \\
\text { y }\end{array}$ & $\begin{array}{l}73 \\
\mathrm{~L}\end{array}$ \\
\hline 326 & $\begin{array}{l}\text { Leopold Levy } \\
(1882-1966)\end{array}$ & Landscape & 20.07 .1939 & $\begin{array}{l}17 \times 25 \mathrm{~cm} \\
\text { Etching } \\
\text { (ofort) }\end{array}$ & $\begin{array}{l}\text { From } \\
\text { Fine } \\
\text { Arts } \\
\text { Academ } \\
\text { y }\end{array}$ & $\begin{array}{l}73 \\
\mathrm{~L}\end{array}$ \\
\hline 327 & $\begin{array}{l}\text { Leopold Levy } \\
(1882-1966)\end{array}$ & Landscape & 20.07 .1939 & $\begin{array}{l}16 \times 24 \mathrm{~cm} \\
\text { Etching } \\
\text { (ofort) }\end{array}$ & $\begin{array}{l}\text { From } \\
\text { Fine } \\
\text { Arts } \\
\text { Academ } \\
\text { y }\end{array}$ & $\begin{array}{l}73 \\
\mathrm{~L}\end{array}$ \\
\hline 328 & $\begin{array}{l}\text { Leopold Levy } \\
(1882-1966)\end{array}$ & Landscape & 20.07 .1939 & $\begin{array}{l}14.5 \times 20 \mathrm{~cm} \\
\text { Etching } \\
\text { (ofort) }\end{array}$ & $\begin{array}{l}\text { From } \\
\text { Fine } \\
\text { Arts } \\
\text { Academ } \\
\text { y }\end{array}$ & $\begin{array}{l}73 \\
\mathrm{~L}\end{array}$ \\
\hline 329 & $\begin{array}{l}\text { H.Verge } \\
\text { Sarrat(1880- } \\
1966)\end{array}$ & Landscape & 20.07 .1939 & $\begin{array}{l}15.5 \times 21.5 \mathrm{~cm} \\
\text { Etching } \\
\text { (ofort) }\end{array}$ & $\begin{array}{l}\text { From } \\
\text { Fine } \\
\text { Arts } \\
\text { Academ } \\
\text { y }\end{array}$ & $\begin{array}{l}73 \\
\mathrm{~L}\end{array}$ \\
\hline 330 & H.Verge Sarrat & Branches & 20.07 .1939 & $\begin{array}{l}24.5 \times 19 \mathrm{~cm} \\
\text { Etching } \\
\text { (ofort) }\end{array}$ & $\begin{array}{l}\text { From } \\
\text { Fine } \\
\text { Arts } \\
\text { Academ } \\
\text { y }\end{array}$ & $\begin{array}{l}73 \\
L\end{array}$ \\
\hline 331 & $\begin{array}{l}\text { A.Dunoyer de } \\
\text { Segonzac (1884- } \\
\text { 1974) }\end{array}$ & Landscape & 20.07 .1939 & $\begin{array}{l}18.5 \times 13.5 \mathrm{~cm} \\
\text { Etching } \\
\text { (ofort) }\end{array}$ & $\begin{array}{l}\text { From } \\
\text { Fine } \\
\text { Arts } \\
\text { Academ } \\
\text { y }\end{array}$ & $\begin{array}{l}73 \\
L\end{array}$ \\
\hline 332 & $\begin{array}{l}\text { A.Dunoyer de } \\
\text { Segonzac }\end{array}$ & Women Lying & 20.07 .1939 & $\begin{array}{l}14 \times 19 \mathrm{~cm} \\
\text { Etching }\end{array}$ & $\begin{array}{l}\text { From } \\
\text { Fine } \\
\text { Arts } \\
\text { Academ } \\
\text { y }\end{array}$ & $\begin{array}{l}73 \\
\mathrm{~L}\end{array}$ \\
\hline 333 & Eduard Kayser & Landscape & 20.07 .1939 & $\begin{array}{l}18 \times 25 \mathrm{~cm} \\
\text { Etching } \\
\text { (ofort) }\end{array}$ & $\begin{array}{l}\text { From } \\
\text { Fine } \\
\text { Arts } \\
\text { Academ } \\
\text { y }\end{array}$ & $\begin{array}{l}73 \\
L\end{array}$ \\
\hline 334 & $\begin{array}{l}\text { Raoul Dufy } \\
(1877-1953)\end{array}$ & Sea and Boats & 20.07 .1939 & $\begin{array}{l}35.5 \times 50 \mathrm{~cm} \\
\text { Litography }\end{array}$ & $\begin{array}{l}\text { From } \\
\text { Fine } \\
\text { Arts }\end{array}$ & $\begin{array}{l}73 \\
\mathrm{~L}\end{array}$ \\
\hline
\end{tabular}




\begin{tabular}{|c|c|c|c|c|c|c|}
\hline & & & & & $\begin{array}{l}\text { Academ } \\
\mathrm{y}\end{array}$ & \\
\hline 337 & $\begin{array}{l}\text { Charles Despiau } \\
(1874-1946)\end{array}$ & Nude & 20.07 .1939 & $\begin{array}{l}34.5 \times 24 \mathrm{~cm} \\
\text { charcoal on } \\
\text { paper }\end{array}$ & $\begin{array}{l}\text { From } \\
\text { Fine } \\
\text { Arts } \\
\text { Academ } \\
\text { y }\end{array}$ & $\begin{array}{l}86 \\
L\end{array}$ \\
\hline 338 & $\begin{array}{l}\text { Henr1 Matisse } \\
(1869-1954)\end{array}$ & Nude & 20.07 .1939 & $\begin{array}{l}21.5 \times 10 \mathrm{~cm} \\
\text { Etching }\end{array}$ & $\begin{array}{l}\text { From } \\
\text { Fine } \\
\text { Arts } \\
\text { Academ } \\
\text { y }\end{array}$ & $\begin{array}{l}73 \\
L\end{array}$ \\
\hline 339 & $\begin{array}{l}\text { Henr1 Matısse } \\
(1869-1954)\end{array}$ & Ballerina & 20.07 .1939 & $\begin{array}{l}29.5 \times 47 \mathrm{~cm} \\
\text { Litography }\end{array}$ & $\begin{array}{l}\text { From } \\
\text { Fine } \\
\text { Arts } \\
\text { Academ } \\
\text { y }\end{array}$ & $\begin{array}{l}73 \\
L\end{array}$ \\
\hline 340 & $\begin{array}{l}\text { Charles Dufresne } \\
(1876-1938)\end{array}$ & Bar & 20.07 .1939 & $\begin{array}{l}20 \times 26 \mathrm{~cm} \\
\text { Etching }\end{array}$ & $\begin{array}{l}\text { From } \\
\text { Fine } \\
\text { Arts } \\
\text { Academ } \\
\text { y }\end{array}$ & $\begin{array}{l}73 \\
L\end{array}$ \\
\hline 341 & $\begin{array}{l}\text { Pablo Picasso } \\
(1881-1981)\end{array}$ & $\begin{array}{l}\text { Painter and his } \\
\text { model }\end{array}$ & 20.07.1939 & $\begin{array}{l}22 \times 28.5 \mathrm{~cm} \\
\text { Etching }\end{array}$ & $\begin{array}{l}\text { From } \\
\text { Fine } \\
\text { Arts } \\
\text { Academ } \\
\text { y }\end{array}$ & $\begin{array}{l}73 \\
L\end{array}$ \\
\hline 342 & $\begin{array}{l}\text { Pablo Picasso } \\
(1881-1981)\end{array}$ & $\begin{array}{l}\text { Painter and his } \\
\text { model }\end{array}$ & 20.07 .1939 & $\begin{array}{l}22 \times 28.5 \mathrm{~cm} \\
\text { Etching }\end{array}$ & $\begin{array}{l}\text { From } \\
\text { Fine } \\
\text { Arts } \\
\text { Academ } \\
\text { y }\end{array}$ & $\begin{array}{l}73 \\
L\end{array}$ \\
\hline
\end{tabular}

Table 1) List of Paintings in the MSGSU, Istanbul Painting and Sculpture Museum inventory record These 26 works are listed in the records of the museum. But in the records it is stated that they have been bought from Fine Arts Academy in 20th of July 1939. And in the records there is no information about Selahattin Refik Sirmalı.

\section{A groupe of foreign artists in the collection and thir connections with Léopold-Lévy}

These foreign artists [Pablo Picasso (1881-1973), Dunoyer de Segonzac (1884-1974), Henri Matisse (1869-1954), Charles Despiau ( 1874-1946), RaoulDufy (1877-1953), Jean-Emile Laboureur (18771943), Charles Dufresne (1876-1938), Charles Edmond Kayser (1882-1965), Henri Verge Sarrat (1880-1966), Pierre Bonnard (1867-1947), André Derain (1880-1954), Albert Marquet (1875-1947), Maurice Utrillo (1883-1955)] in the collection are all the members of French school and they are representatives of modern painting. They are also contemporaries with Léopold-Lévy. Considering the background of Lévy it is remarkable that in his career he had relations and intersections with some of these artists.

Charles Dufresne (1876-1938): Léopold-Lévy has been an important figure in the art milieu of France during the mid 1920's. In this period he has taught at the Scandinavian Academy instead of his friend 
Charles Dufrense. It was his first teaching experince before his appointment to Istanbul Fine Arts Academy. (Demir, 2009: 263)

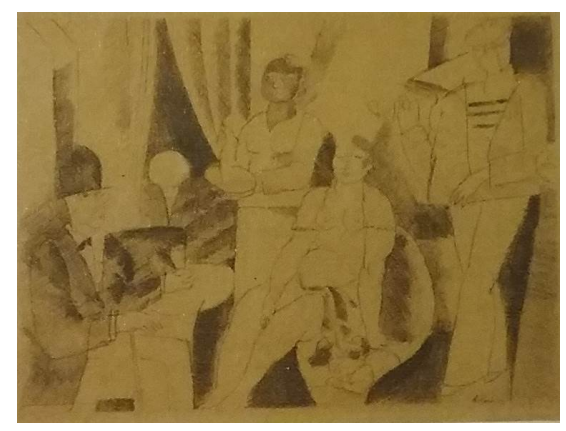

Picture 2.Charles Dufresne, Bar, etching, 20x26cm,MSGSU, Istanbul Painting and Sculpture Collection ((Ref. Katipoğlu, H. (ed.) (1996). İstanbul Resim Heykel Müzesi Kataloğu, YKY, İstanbul, s.515)

Charles Despiau ( 1874-1946): Charles Despiau was an artist with whom many Turkish sculptors had been studied in Paris. He was a friend of Léopold-Lévy and he has offered Lévy for the Academy of Fine Arts in İstanbul. (Üstünipek, Ş.,2009: 461)

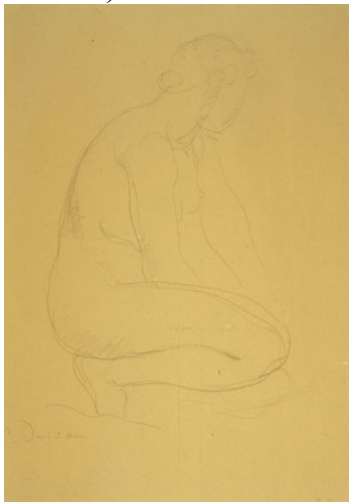

Picture 3.Charles Despiau, Nude,charcoal on paper, $34,5 \times 24,5 \mathrm{~cm}$, MSGSU, Istanbul Painting and Sculpture Collection(Ref. Katipoğlu, H. (ed.) (1996). İstanbul Resim Heykel Müzesi Kataloğu, YKY, Istanbul, s.514)

Edouard Kayser (1882- 1965) and H. Vergé Sarrat (1880-1966):Léopold-Lévy and his friends Edouard Kayser (1882- 1965) and H. Vergé Sarrat (1880-1966) have been studied together in the gravure atelier of Heyman, the grandson of Jean François Millet (1814- 1875). Léopold-Lévy has written out an article after the death of Kayser in 1965.

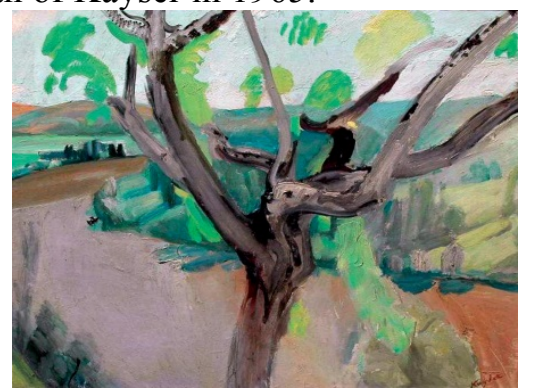

Picture 4.Edmond Kaiser, Tree and Road, oil on wood, $25 \times 18 \mathrm{~cm}$, MSGSU, Istanbul Painting and Sculpture Col. (Ref. Katipoğlu, H. (ed.) (1996). Ístanbul Resim Heykel Müzesi Kataloğu, YKY, Istanbul, s.518) 


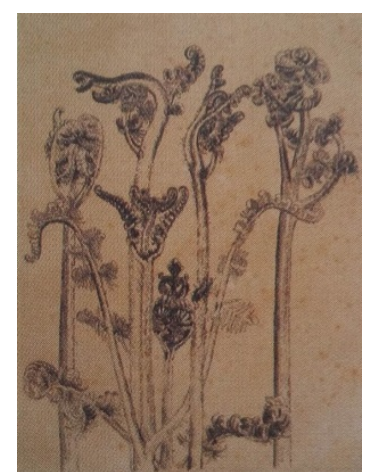

Picture 5.H.Verge Sarrat, Plant Motifs, 1911, etching, 24,5x19cm, MSGSU, Istanbul Painting and Sculpture Collection. (Ref. Katipoğlu, H. (ed.) (1996). İstanbul Resim Heykel Müzesi Kataloğu, YKY, Istanbul, s.525)

Henri Matisse (1869-1954) and Albert Marquet (1875-1947): Lévy has worked along with Matisse and Marquet at the fresco decoration of 1900 Exhibition for to earn his keeping.

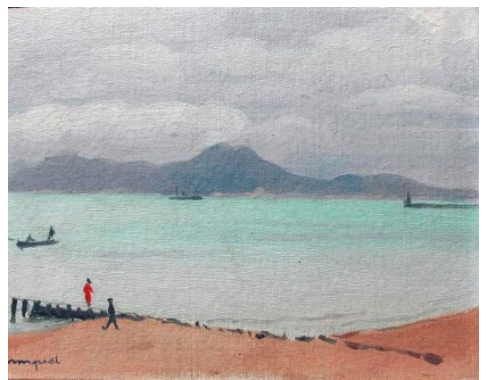

Picture 6.Albert Marquet, Impressions from Napoli, Oil on canvas, 21,5×26,5 cm, MSGSU, Istanbul Painting and Sculpture Collection(Ref. Katipoğlu, H. (ed.) (1996). İstanbul Resim Heykel Müzesi Kataloğu, YKY, İstanbul, s.523)

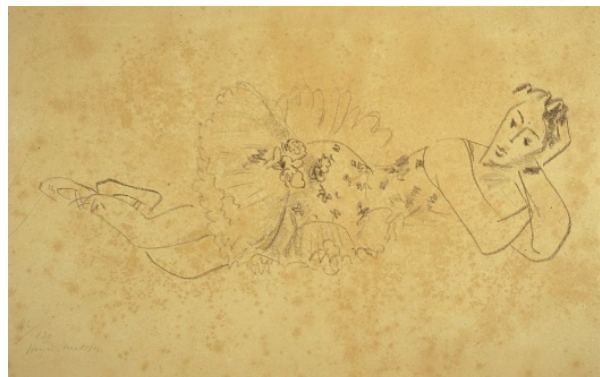

Picture 7.Henri Matisse, Ballerina, 29.5x47 cm, Litography, Istanbul Painting and Sculpture Collection(Ref. Katipoğlu, H. (ed.) (1996). İstanbul Resim Heykel Müzesi Kataloğu, YKY, İstanbul, s.522)

André Derain (1880-1954): Dufy, Matisse and Derain whose works are in the collection of Istanbul Painting and Sculpture Museum are the major figures of Fauvism. Lévy has also been in touch with fauvism in his early career. He has made some colorist Southern France landscapes and has joined exhibitions with fauvist painters. He has shared an atelier with Andre Derain to whom he had left the atelier when he has moved to Istanbul. (Üstünipek, Ş.,2009: 421) 


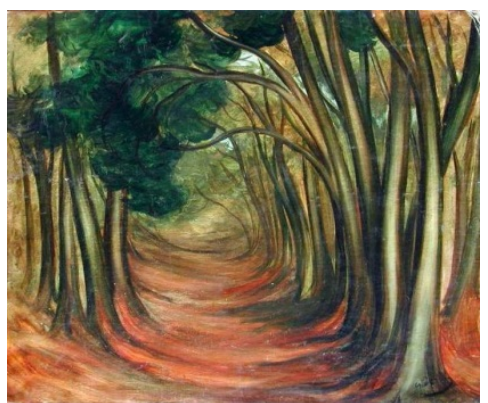

Picture 8.Andre Derain; Road Lined with Trees, oil on canvas, 46x56cm, MSGSU, Istanbul Painting and Sculpture Collection(Ref. Katipoğlu, H. (ed.) (1996). Ístanbul Resim Heykel Müzesi Kataloğu, $Y K Y$, Istanbul, s.145)

\section{In Turkish Press news and articles on artists of foreign collection in the museum}

Considering the Turkish news of 1937- 1944 period these paintings in the collection have been regarded as the examples of modernism in art. Works of the artists in the collection have been a subject for many articles in Turkey. For instance in his article titled "Modernizmin Resmi Hikmeti" (Modernisms Official Wisdom) dated 28th of April 1938, Peyami Safa has related the expression of Lévy that representatives of modern painting were invited to the juries at the Paris academy of Fine Arts same as in Turkey. There were painters Vuillard, Segonzac, sculptors Maillol, Despiau, Drivier, Poisson and architect Tony Garnier in the juries. (Safa, $1938: 3$ )

In an article dated 9th of March 1939 and titles "Münzevi Sanatkar Utrillo" (Secluded Artist Utrillo) it has been mentioned that the works of Utrillo were refused by the customs. (Anonymuse 1939: 6)

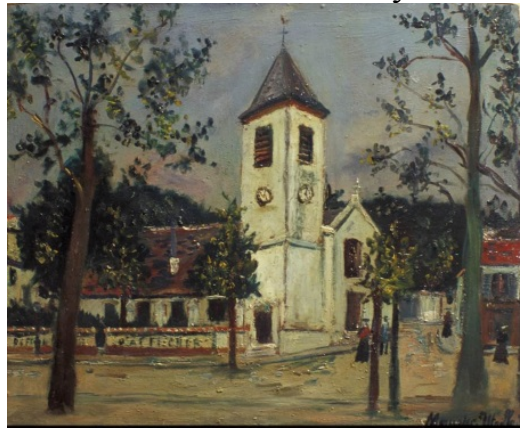

Picture 9.Maurice Utrillo; Church Between Trees, oil on board, 38x46 cm, MSGSU, Istanbul Painting and Sculpture Collection(Ref. Katipoğlu, H. (ed.) (1996). İstanbul Resim Heykel Müzesi Kataloğu, YKY, Istanbul, s.143)

In an article dated 17 January 1940, introducing the exhibition of Levy's students' it has been related the statements of Burhan Toprak on 1936 reformations at the Academy. In the same article it has been defined that Paris Fine Arts Academy was also aiming to make that kind of reorganization by offering professorship to Despiau, Segonzac, Friesz and Derain. (Anonymusg, 1940: 6)

In 14th of February 1941, Lévy has written out an article for the nineth exhibition of Group d titled "İki Sergi, Üç Nesil, Bir İbret Dersi” (Two Exhibitions, Three Generations, One Object Lesson). He has made references to the Contemporary French Painting exhibition in 1940 at the French Consulate in İstanbul. He has introduced Bonnard, Matisse, Derain, Segonzac's contributions to the French art and has claimed that the concerns of the artists of Group $\mathrm{d}$ were to maintain great French tradition. (Levy, 1941: 3)

In his article "Bugünün Sanatı" (Today's Art) dated 1st of October 1941 Burhan Toprak has based upon the art of Andre Derain while describing artistic beauty.(Toprak, 1941:2) In his article "Bonnard 
ve d Grubu" (Bonnard and Group d) dated 5th of May 1944 Fikret Adil has announced that there were paintings of Bonnard and Lévy in Group d exhibition and he has introduced Bonnard's life and art. (Adil, 1944: 3)

In his article on gravure art "Bugünkü Müstakil Gravürler" (Today's Independent Gravures) Sabri Berkel has claimed that the most successful gravure artists of the day were in France and he has mentioned that some of them were in the collection of Istanbul Painting and Sculpture Museum. (Berkel, ; 68)

\section{CONCLUSION}

It is not certain the source of the works of foreign artists in the museum and from which collection they had been bought. Altough in his speech Burhan Toprak has given the name of Selahattin Refik Sirmalı there are no other records to prove that they have been bought from him by the Academy. In an interview with Tiraje Dikmen she has claimed that these paintings have been bought from Sirmali and Lévy has organized their acquisition for the museum. (Üstünipek,2009:422)

There is another situation that supports this hypothesis. Lévy has arrived in Istanbul in December 1936. He has begun to work at the Academy instantly. But his position at the school has been finalized in 1st of March 1937. With a following enactment his inauguration has been fixed to February. However he has possibly had financial problems in January and February in a period following his arrival to Istanbul with his family until his position approved at the Academy on March. During this period it is possible to make an inference that he has sold his collection of the mentioned foreign artists to Selahattin Refik Sirmalı. These are all supposal but in any case Lévy has made an important conribution to enrich the museum collection by curating the inclusion of some Turkish and foreign painters.

As a result of Turkish Republic's modernization process there have been a reformation at the Academy and foreign professors have been appointed to the school. Thus a more modernized educational system has been established. It has been a necessity to organize a painting and sculpture museum for the new educational system. Forming its own collection the museum has made acquisition of a collection which was involving 26 pieces of well known foreign artists. This collection is introducing the School of Paris and modern painting. During the self enclosed period of Second World War this collection has been a model and inspiration for Turkish artists and critics.

\section{REFERENCES}

Adil, F. (1944). "Bonnard ve d Grubu”, Cumhuriyet, 5 Mayı 1944, s.3

Anonymusa. (1938). "Ressam Leopold Levi Dün Zengin Bir Sergi Açtı", Cumhuriyet, 17 Nisan 1938, s.9

Anonymusb. (1934). Ylldız sarayı tefrişi projesi, Arkitekt, 1934/1, s.8)

Anonymusc. (1934). "Yıldı Sarayl yeniden tefriş ediliyor", Cumhuriyet, 23 Şubat 1934, s. 2

Anonymusd.(1937). "Dekorasyon Sanatının Tamimi”, Cumhuriyet, 15 May 1937, s.2

Anonymuse. (1939). "Münzevi Sanatkar, Utrillo şimdi herkesi kendisi ile meşgul ediyor”, Cumhuriyet, 9 Mart 1939, s.6

Anonymusf. (1939). "Resim Heykel Müzesi Tekrar Açıldı”, Cumhuriyet, 16 Temmuz 1939, s.2

Anonymusg. (1940). "Dün Akademide açılan talebe resim sergisi”, Cumhuriyet, 17 Ocak 1940, s. 6

Archivea. (1937) Başbakanlık Cumhuriyet Arşivi, 24 July 1937 tarihli belge.

Archiveb. MSGSÜ, İstanbul Resim Heykel Müzesi Arşivi

Berkel, S. "Gravür Hakkında", Güzel Sanatlar, S.1, s.68

Demir, A. (2009). Güzel Sanatlar Akademisi’nde Yabancı Hocalar, MSGSÜ Yayını, İstanbul

Ethem, H. (1970). Elvah-ı Nakşiye Koleksiyonu, Milliyet Yayınlarl, İstanbul 
Germaner, S. (Ed.) (2009). İstanbul Resim Heykel Müzesi, 1937 Açılış Koleksiyonu:Serginin sergisi:İstanbul Painting and Sculpture Museum, 1937 opening collection, Mimar Sinan Güzel Sanatlar Üniversitesi Yayını, İstanbul

Katipoğlu, H. (ed.) (1996). İstanbul Resim Heykel Müzesi Kataloğu, YKY, İstanbul

Lévy, L.(1941). "IKİ SERGİ, Ü̧̧ nesil- bir ibret dersi”, Cumhuriyet, 14 Şubat 1941, s.3

Safa, P. (1938). "Modernizmin resmi kıymeti", Cumhuriyet, 28 Nisan 1938, s. 3

Tollu, C. (1967). "Resim Heykel Müzesi ve Atatürk", Akademi Mimarlık ve Sanat, 7, 1Kasım 1967,s. 38

Tosun, C.., Özsu, C. (2014) “Cumhuriyet Dönemi'nin Art Deco Mobilya Tasartmlarl; Selahattin Refik Sirmalı ve Atatürk'ün Çalışma Odası”, Ankara Araştırmaları Dergisi, Aralık 2014, s.216-235, http://www.journalagent.com/jas/pdfs/JAS $22216235 . p d f$

Toprak, B. (1941). "Bugünün Sanatı”, Cumhuriyet, 1 Birinciteşrin (Ekim) 1941, s.2

Üstünipek, Ş. (2009). "1936-1950 Yıllarl Arası Güzel Sanatlar Akademisi: Léopold-Lévy ve Atölyesi”, MSGSÜ, Sosyal Bilimler Enstitüsü, Yayınlanmamış Doktora Tezi, İstanbul

Üstünipek, M. (2011). "Documents on Turkish Painting Exhibition in the International Exhibition of UNESCO in 1946: Turkish Painting's Reconnection with Paris and Its Results", $14^{\text {th }}$ International Congress of Turkish Art, 19-21 September 2011, Paris, Collége de France, Collége de France, Paris, 2013, s. 819-824

Yaman, Z.Y.; Bauhaus ve Söylemleştirilen İç Mekan Anlayışı: Yeni Yaşam, Yeni Dekorasyon, Yeni Mobilya, Ev ve Dekorasyon ve Mobilyacilik, https://www.academia.edu/4190404/Bauhaus ve S\%C3\%B6ylemle\%C5\%9Ftirilen \%C4\%B0\% C3\%A7 Mekan Anlay\%C4\%B1\%C5\%9F\%C4\%B1 Yeni Ya\%C5\%9Fam Yeni Dekorasyon Ye ni Mobilya 